\title{
Forms And Functions Of Sandstone Handicrafts In Singapadu Kaler Village In The Global Era
}

\author{
I Ketut Muka Pendet ${ }^{1}$, Ni Made Rai Sunarini² \\ Indonesian Institute of the Arts Denpasar
}

iketutmuka14@yahoo.com

\begin{abstract}
In this era, the forms and functions of sandstone handicrafts in Singapadu Kaler Village have undergone very rapid development and change. This is marked by the emergence of various types of sandstone handicrafts, which enrich the arts and culture of Bali in particular and Indonesia in general. Several forms of sandstone handicrafts produced by craftspeople in Singapadu Kaler Village are very popular and much in demand by consumers. Among these are garden lampshades, wall lights, ventilation decor, flower pots, fauna and flora bas-relief, statues of the Buddha, and other sculpture motifs. These forms have a different function, style and aesthetic impression than traditional sandstone handicrafts in other regions. Overall, the products were created as a result of the influence of globalization, which gave birth to a wide variety of forms and innovations. Hence, it is important to write about so that the forms and functions as well as the messages contained within them can be clearly revealed. A qualitative interpretive method was used to analyze this phenomenon with a cultural studies approach utilizing deconstructivist theory and postmodern aesthetic theory. This lead the authors to the general conclusion that these new forms and functions of sandstone handicrafts have given rise to positive and negative impacts, which have not only been accepted by the craftspeople, but also the broader community of Singapadu Village and consumer society. In addition, these handicrafts also contain important creative, economic, aesthetic, and cultural change functions. This brief article hopes to be useful as a medium for study by secondary and higher education institutions of art or the general public about the field of sandstone handicrafts growing in Singapadu Kaler Village. It also hopes to be a useful reference for writers and researchers in other regions, so that the repertoire of scientific knowledge on sandstone handicrafts in Indonesia can become more widely known.
\end{abstract}

Keywords: sandstone handicrafts and globalization

\section{Bentuk Dan Fungsi Kerajinan Batu Padas Desa Singapadu Kaler Gianyar Pada Era Global}

Dewasa ini bentuk dan fungsi kerajinan batu padas di Desa Singapadu Kaler mengalami perkembangan dan perubahan sangat pesat. Hal ini ditandai munculnya berbagai jenis kerajinan batu padas dengan fungsi yang berbeda sehingga memperkaya khasanah seni budaya Bali khususnya dan di Indonesia pada umumnya. Ada beberapa bentuk dan fungsi kerajinan batu padas yang sangat populer dan diminati para konsumen merupakan produksi perajin-perajin dari Desa Singapadu Kaler Gianyar. Bentuk kerajian batu padas tersebut memiliki fungsi, gaya dan kesan estetis yang berbeda dengan bentuk kerajinan batu padas tradisional didaerah lain. Secara keseluruhan kerajinan yang diciptakan tersebut pada dasarnya akibat dari pengaruh globalisasi, sehingga melahirkan bentuk dan fungsi kerajinan batu padas yang sangat variatif dan inovatif. Hal tersebut berdampak positif dan negatif tidak saja diterima oleh para pengrajin, namun lebih luas, pada masyarakat desa dan masyarakat konsumen. Selain itu, bentuk dan fungsi kerajinan batu padas di Desa Singapadu Kaler secara umum mengandung fungsi yang bereka macam dan sangat penting, antara lain: fungsi kreatipvitas, ekonomi, estetis, dan fungsi perubahan budaya. Metode yang dipakai untuk menganalisis permasalahan adalah kualitatif dengan pendekatan kajian budaya, memanfaatkan, teori dekonstruksi, dan teori estetika postmodern. Tulisan ini diharapkan dapat dipakai sebagai media pembelajaran baik oleh lembaga pendidikan seni tingkat menengah dan perguruan tinggi atau masyarakat umum, khususnya dalam bidang kerajinan batu padas yang berkembang di Desa Singapadu Kaler Gianyar. Di samping itu tulisan ini juga dapat dijadikan acuan oleh para penulis dan peneliti dalam melakukan penelitian ilmiah yang lain, agar khasanah ilmu pengetahuan seni kerajinan batu padas di Indonesia semakin diketahui dan berkembang dengan pesat.

Kata Kunci: Kerajinan Batu Padas dan Globalisasi. 


\section{INTRODUCTION}

Since prehistoric times (8000--5000 BC) many products of art and culture have been found in Gianyar such as the discovery of the sarcophagus, nekara, relief, rock temples, statues, sculptures and relics of other stones (Kempers, 1977: 122). These remains contain garnish demonstrating ancestors proficiency in making scratches in the form of masks, carvings, statues and other ornaments. Artifacts of culture in the form of sculptures, reliefs found at the tourism object of Yeh Pulu, Goa Gajah Bedulu Village; Bebitra Cliff Temple and Cliff Temple of Gunung Kawi, Tampaksiring. So many archaeological remains are full of multiple meanings intrinsically useful to the systemic, academic, ideological, strategic importance in strengthening the nation's character and can provide economic value in a sustainable manner.

The development of limestone craftsart in the village of Singapadu Kaler in line with the current journey of times by displaying its own characteristics, which is pioneered by young-talented craftsmen with formal education so that they can bring innovative creative works. The diversity of limestone craftpatterns in the village of Singapadu Kaler up till now being is continuously developed and still based on the traditional elements and local value. Viewed in terms of production and sales of handicrafts it can trigger motivation of the craftsmen to work and create. They take advantage of the atmosphere by participating actively to make a breakthrough and try to explore new innovations in the field.

Singapadu Kaler village is the center of the limestone craft industry well known by people around the world since the 1970 s, and nearly $75 \%$ of the local people are the crafters. Judging from the character, form, and function of traditional crafts and the onesthat are thriving today, they still reflect the peculiarities of its own identity. It can be observed as a whole and in detail, both in terms of design, decorative ornaments, textures, materials and production techniques showing that the beauty of the composition and proportion are always taken into consideration. The concept of traditional limestone craft creation in the village of Singapadu Kaler, Gianyar, is still aimed at the interests of Hindu religion reflecting the scheme or form that transcends human experience, feudalistic, and communal. In line with Soedarso's view (1992: 45), the concept of creation leads to the interests of the king (ruler) that bringing about the traditional craft forms that follow certain norms in the sense that the characteristics of traditional Balinese limestone crafts have meaning and symbolic meaning, religious magical in nature, like the embodiment of the gods and goddesses, such as building decoration of kekarangan, pepatran and relief (Covarrubias, 1957: 191).

The diversity of shapes with smooth character, such as, figures of gods, warriors; rough characters, such as the myth of ghosts, giants; and old character with typical narrow eyes, and their position take symmetrical placement as a decoration of sacred buildings / temple referring to the views of classical aesthetics. The art is described by the principle of form follows meaning, in the sense that in arranging the artwork the artisans look to give more priority to new ideological significance, with the overall appearance refering to the shape of a symmetrical composition that gives the meaning of harmony with the concept of creation guided by the norms and certain grip.

In general the embodiments of limestone craft of Singapadu Kaler village very clearly take the forms of wayang Bali using three dimensional proportions, namely (1) lanjar, specifically to create a high-scale sculpture or placed at a height; (2) nyepek, following the measure of a man; and (3) rentet, specially clown shapes and funny sculptures This was done due to the fact that all arrangement of shapes, symbols, disposition or expression, and decorative ornaments, creation still follow the norms of tradition that always has sacred impression unlike other forms of modern limestone crafts developed by young craftsmen that do not reveal the exact size, ignoring traditional norms so that it looks sometimes asymmetrical, clumsy, eccentric and funny, giving meaning rebellion and lack of balance.

\section{GLOBALIZATION}

Globalization means the disappearance process of distance, the dimensions of time and space that used to be long and far to become very close. Globalization refers to the narrowing of world intensively and increase our awareness of the world. Firmasanzah in Yudabakti (2013: 33) mentions that globalization is also an endless process of integration dragging things that are locally attached to the characteristics of the origin leading to the global nature of things that circulate freely without limits. Giddens (2003: 73) states that globalization is not purely economical, both in terms of the nature, causes and consequences. Globalization movement is also social, political, and cultural touching the field of culture in society, including the arts.

The rapid impact of globalization to Bali, especially in Gianyar unwittingly has shifted the various forms of local culture and seeks to acknowledge, even mingles with global culture. This process eventually results in a mixed culture which is supported by a wide range of heterogeneous cultural elements to create innovation or a form of new culture, both adopted from foreign influence and the results of internal development and creativity of the local communities. It happens gradually and slowly changes the perspective and the concept of thinking of the craftsmen to continue exploring new values in the creation.

Handicraft products that were once seen as valuable works are now in the era of globalization greatly influenced by the market, consumers (stakeholders). This is caused by a 
global culture that is identical with market culture that is more concerned with economic value and use rather than the content.This view was pioneered by young artisans with formal education with the concept of creation that is more directed to the interests of the market, both in terms of form, the characters are more innovative, and functional, all lookt leading to modern aesthetics and postmodern form following function (form follows function) and forms follow pleasure (form follows man) abandoning the concept of creation that is guided by norms and certain grip. The influence of globalization occurring in the village of Singapadu Kaler Gianyar influences the disappearance of style, unwittingly threatens the existence of a variety of local cultural heritages, even mingle with the global culture This is reflected by the birth of new ideas and concepts of limestone craft creation by utilizing modern technology in order to create new forms and gradually shift the craft functions of limestone craft into practical interests. The birth of a new idea with the development of modern and appropriate technology makes entrepreneurs and creative artisans produce a variety of products of modern culture.

\section{LITERATURE REVIEW}

Associated with the title of this writing a search and study of some books that are related to craft and culture of Bali have been carried out, including Bali di Persimpangan Jalan, by Usadi Wiryatnaya and Jean Couteau (1995) that essentially describes a social change; Musnahnya Otonomi Seni by Djuli Djatiprambudi (2009) describes the art product today has led to market interests; Indonesia Heritage, written by Soemantri Hilda (1999) mapped out in detail the development of art since the time of Pita Maha Bali.

Perceptions of Paradise: Image of Bali in The Art written by Garret Kam (1993); explained that the development of art in Bali can be grouped into two sections. First, discusses the history of Balinese art starting from prehistoric times to the present. Both discuss the traditions and changes of Balinese art, especially in visual form, and Art in Indonesia: Continuittes and Change, a book written by Clair Holt (1967) clearly describes arts development in Indonesia to sculpture in Bali that are turned on by tradition and Hinduism. Religious activities in Bali, especially Hinduism can be used as the basis of life and the concept of the creation of the arts of Bali. Furthermore, it is stated that the sculpture in Bali has changed direction into secular after obtaining external influences (West). The relevance of the above writings can be used as a reference in getting the concepts and theories that are beneficial to add insight in assessing the form and function of limestone crafts in Singapadu Kaler village on the global era.

\section{METHODOLOGY}

The method used to obtain field data is qualitative and cultural studies approach. Qualitative method is a method of research that holds on field data with observations, interviews, and supported by documentation method. This research is cultural studies with a qualitative approach and potpositivistic paradigm then the relevant method used is a qualitative method. The method is used with the consideration that the overall field data collection uses an approach that tends to use words verbally to narrate the form and function of limestone craft as a phenomenon of cultural arts in the village of Singapadu Kaler. Postpositivistic paradigm is the paradigm of research that not only examines the reality of what can be seen, touched and felt, but also to understand and examine the meanings behind the reality (Satori and Komariah, 2010: 12).

Black and Champion (1999: 66; Ratna, 2010: 289) also mentions, that the case study or postpositivistic more dominantly uses the services of informants. Referring to the opinion, the study of form and function of limestone crafts on global era in the village of Singapadu Kaler is a form of case study or postpositivistic that mostly uses the services of informants. Principally the research is a case study related to the form and function of limestone crafts and its development in the global era.

Qualitative research method used is not only in the workings of systematic thinking and reflective study to understand the form and function of limestone crafts in the village of Singapadu Kaler but also is an opportunity to correct the initial assumption that the village of Singapadu Kaler is a cultural region or limestone craft centers which is already known to the public from foreign countries.

\section{Forms and Functions of Sandstone Handicrafts}

The discussion on the form and function of limestone crafts in the village of Singapadu Kaler, is not only an aesthetic presentation as a cultural product in the sense of beauty, but also gives pleasure and enjoyment, created as a legacy of tradition. The form and function of limestone crafts on globalization era is seen as an esthetic offer constructed for capitalist interests with the development of traditional values, regional identity, and the novelty that brings about ideology that encourages the existence of handicrafts to meet the needs of the present market share.

Effort and movement of changes are made for the production of traditional limestone crafts are increasingly not in demand for its creation is only based on religious interests and supporting the beauty of the temple buildings and housing. Therefore, some young artisans raised initiative to adopt modernization to deconstruct back the motifs and forms of traditional crafts in anticipation of the growth of tourism facilities. This shift in perspective is what lies behind the pattern of thought and the creation concept of the young artisans that cthat gave birth to limestone craft works that more lead to the global market orientation.

The development of tourism in the village of Singapadu Kaler strongly influenced the shape, distribution, and consumption of the limestone crafts. As revealed by Ar- 
dika (2003) that the development of tourism in Bali can not be separated from the facilities, hotels, villas, home stays, restaurant and spa. In addition it also takes art crafts, both with traditional and modern identities, as a supporting element of the aesthetic space, architecture, and gardens. It affects the growth of limestone crafts in the village of Singapadu Kaler with the concept of creation that leads to postmodern aesthetic, abandoning the concept of traditions based on the norms and certain grip. Slowly it shifts the role of traditional artisans. In addition unwittingly they are marginalized by the birth of new concepts with the minimalist craft design to meet consumer demand and contemporary tourism.

Since the limestone crafts in the village of Singapadu Kaler are developed as a commodity, especially for the needs of the aesthetic elements of space, some artisans began to move the profession or have dual function, namely as a craftsman and entrepreneur or distributor (art dealer). The dual role of craftsmen indirectly make the distance between traditional craftsmen and young artisans who pursue new models, especially in the development of structures and design motifs. The spirit of creativity of the young artisans, collectors, and entrepreneurs in creating and developing new innovations, good ideas, ideas, design technique, as well as more modern production. This dilemma brings about problems for the growth of traditional limestone crafts in the village of Singapadu Kaler.

Conditions that lead to the production of limestone crafts in the village of Singapadu Kaler they are under the hegemony of capitalist causing the bending process of pure creativity of the traditional craftsmen who maintain art idealism to become marginalized. If the symptoms are not addressed wisely, either individually or in groups, they can only weaken and destroy the regional identity. The pattern of social and cultural everyday life of young craftsmen in Singapadu Kaler Village lately shows global culture lifestyle. The thoughts and insights of society in producing limestone crafts has been opened in accordance with the situation and market conditions. Hence the concept of thinking, perspectives, and techniques in producing limestone craft forms tend to be modern now.

Since 2006 the craftsmen have adopted material white limestone imported from Palimanan and Pandanwangi Yogyakarta. In addition, the technique has utilized the recycling of powder material of local limestone. The creativity made out of the postmodern concept principally aims to reduce production costs and to avoid damage to the natural environment of Bali. They began to innovate utilizing modern techniques. One of them is to a pour print system using limestone powder materials or recycling system composed with cement, gypsum, and powders.

The production of limestone crafts in the village of Singapadu Kaler has been progressing, no longer limited to materials in the form of limestone taken directly from nature, but a work of art crafts by utilizing the materials in the form of powdered limestone from excavation waste treated with a mixture of cement then molded with the casting technique. Lately, the use of materials continues to grow by bringing materials from the white limestones from Yogyakarta region triggered by the issue of environmental damage and the high cost production.

\section{Forms}

The form of craft art is a cultural work included in the form of attitudes and behavior. Koentjaraningrat (1984: 5) grouped human culture into three, namely the idea or ideas, activities and materials (artifacts). Handicrafts that reveal the nuances of space, line, shape, and texture can be categorized into material manifestation (artifact) as part of the creation of man. The existence of forms, motifs and details that are created can be passed down to the next generation when a variety of shapes, motion lines, motifs, and the nuances of space have been clearly documented.

Speaking about the handicraft as a form of expression of human culture, which flourished in the past is not just one or two forms, but the amount can be grouped according to the shape and place. It can be said that the forms, motifs, and the types of crafts that were created in the past, related to religiousity or places of worship for Hindus. The existence of empirical facts on the field (Singapadu Kaler Village), especially the cultural heritage in the form of artistic reliefs and sculptures, is a translation of ideas and concepts associated with the cult of how high the attention of the authorities towards religious life.

Most legacy of predecessor generation still believed to be a milestone in the introduction of limestone crafts that decorated several temples in the village of Singapadu Kaler are well maintained and sustainable, including the statutes of gods and goddesses, animals, reliefs of the Ramayana, Mahaberata, Tantri, Panji, even other mythological stories. Today the tradition of making statues for the sake of Parahyangan (pura, merajan, sanggah,) still remain to be done by several groups of old craftsmen, while on the other, a group of young craftsmen are more interested in other forms of decorative sculptures (decor), both placed in the yard, hotel, restaurants, on the street, and elsewhere as an aesthetic space element.

However, due to flexibility of most villagers in Singapadu Kaler, these forms of sculptures and statues of ancestral cultural heritage are still maintained and sacred. Such a phenomenon can be said to be the survival of religious attitudes and behaviors of community members that indicates how powerful form of cultural resistance in appreciating the importance of the cultural heritage of the past.

The form of limestone craft is traditional, laden with symbolic value as a form of sacrifice (bhakti) based on the sincerity of mind and attitude (purity), is sacred. Sacred is the nature of human highly subjective form of treatment 
to the symbolic objects on the basis of faith and belief in the greatness of God, such as the embodiment of forms, decorative motifs, either as a supporting structure of the building or simply decoration. Treatment and attitudes of the artisans in the village of Singapadu Kaler in an effort to translate the concepts and ideas into material form of limestones trying to knit the value of traditions of the past as a habit.

According Sztompka (1993: 69) tradition is a whole of material objects and ideas that come from the past and at present still actually exist, undistorted or forgotten. The tradition of the past is still channeled into the present through variants of form based on the elements of modern art. In the artistic process craftsmen in the village of Singapadu Kaler have always relied on the tradition. However, there are times when they undergo a process of idea or concept transformation that has implications for the shape, style and motif, eventually gave birth to more innovative forms of craft that leads to a postmodern aesthetics (Piliang, 2006).

The forms of limestone craft from Singapadu Kaler village can not be separated from the composition or structure of art. The structure implies setting, organizing, connecting, or designing portions of the overall shape. The structure of the artwork is a unity of expressive elements regarding the form and content Djelantik (1990: 32) Soedarso (1993: 2). There are two fundamental factors that can influence the creation of a work of art, namely ideoplastic factors related to the world of ideas that are symbolic and psycoplastic factor that become the real form born from the concept of natural shape sterilization of objects. The experiences underlie the creation of a wide range of shapes and motifs of craft with the composition, proportion, narrative lines and carvings that are trying to uncover the beauty of nature, the value of literature in fragments of Mahaberata story, Ramayana, tantri as well as natural events through allegory implying a symbolic value.

Yudibrata (1982: 56) states that the most important in craft product is the content of its utilitarian value in accordance with the level of practical needs. Therefore, these values appear in an assortment such as religious, spiritual, moral, ethical, aesthetic and practical values. Those values can be drawn from the fundamental point, among others, (1) religion, giving a religious value, magical, and spiritual beliefs; (2) logic, providing the value of intellectual, scientific, science, and empirical truth; (3) ethics, providing a wide range of moral values, manners, moral and ethical; and (4) the aesthetic, rulting in the value of beauty, balance, freshness, entertainment, elegance, and aesthetic. The above criteria very much touch the composition and proportion of the limestone craft forms in the village of Singapadu Kaler, either in the form of two-dimensional shapes, namely keketusan, pepatran, and relief, and the three-dimensional shape such as statues and sculptures as

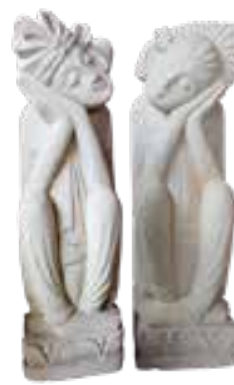

Imitation decorative (pastiche)

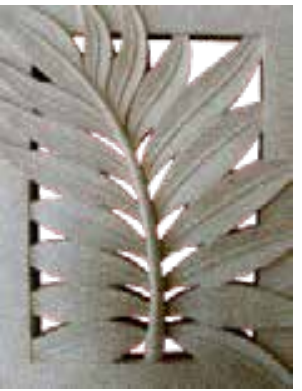

Floral decorative (kitsch)

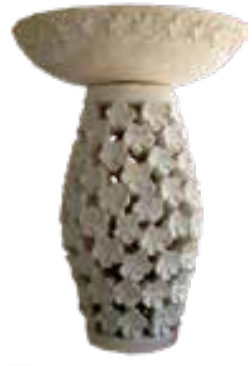

Impressional decorative (parody)

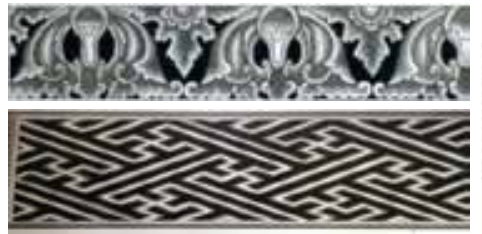

Passive decorative pepatran motif

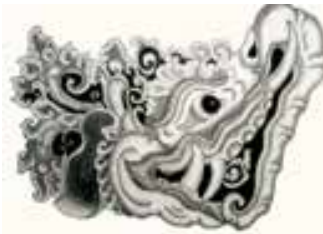

Active decorative kekarangan motif well as forms of limestone crafts today with a postmodern aesthetics touch that overall reflect regional identity.

\section{Functions}

The discussion about the function refers to the opinion of Sedyawati (2008: 293) that from time to time changes frequently occur. The changes will sometimes give rise to new functions or function shift that was not known before, as happened in the village of Singapadu Kaler today. The growth and survival of limestone craft products in the village of Singapadu Kaler were initially just to meet the necessities of the religious. The remains of the culture in the form of statues, sculptures, reliefs, and a wide range of ornaments in the forms of limestone carving used as a medium of communication with the worshipped.

Similarly in other parts of the building elements that use limestone material confirm and give the sense of building function, namely as a dwelling place. The sculptor in the past with the sincere and honest devote all their ability to create art objects taking the forms of statues, sculptures, reliefs, and a wide variety of pragment motifs as decoration on a sacred building that has a function as a means of worship.

Gelebet et al. (1982) state that the placement of a decorative in addition to functioning as a decoration also carries meaning and purpose. The use of ornament can be grouped, such as the decorative as a beauty, decoration as a ritual symbol and decorative as educational media. Similarly, the motifs of craft ornaments carved by the artisans of Singapadu Kaler village reveal the meaning, function, and specific meaning in accordance with its placement. Pepatran motif on building accentuate forms of beauty that are sterilized and abstracted, are for example, the winged lion, handed eagles, winged human, flame-haired 
tortoise, and so forth. Various forms of reliefs, statues, and sculptures are created not only as a form of expression of the artisans, but as a means of communication to the Revered. The motif is bedawang nala as a symbol of stability of life movement, a winged lion as a symbol of agility, and Garuda Wisnu as a symbol of faith.

The appearance of imitation variety of tantri stories, legends that have grown in popularity has a constructive educative meaning. For example, the appearance of lion and bull reliefs from friendship into enmity due to defamation can be interpreted so as not to be easily played off. Forms and decorative motifs are sculpted as decorative of beauty, symbol, educational purposes, and communicative purposes. Lately with the fast growth of tourism the functions are slowly transformed into commercial goods to meet the needs of tourism. In its development many changes occur, including changes in the structure, function, style, and the media.

The function of limestone crafts in the village of Singapadu Kaler, can be translated into three parts, namely personal function, physical function, and social function. The personal function is interpreted that the craft is related as a medium for expressing personal expression in the form of artwork, the social function is the embodiment of art related to social conditions that can affect the collective behavior, while physical function is related to artworks that physically have practical uses such as the creations that can serve as containers and tools.

For more details, the active function of decorative or limestone crafts is visually depicted below. It means that the specific ornament is created to support the building structure as well decorate and the craft group has a passive function only as decoration in accordance with shapes, motifs, and its application in traditional Balinese buildings.

\section{CONCLUSION}

Form and function of limestone craft in the village of Singapadu Kaler are basically triggered by globalization so as to provide opportunities for people to exercise creativity. The community in question is the capital owners or entrepreneurs, communities and artisans who created the limestone crafts. In addition, there are also people who live in and around the village of Singapadu Kaler and consumer society who consume limestone craft products, either from Bali or outside Bali

The development of the form and function of limestone crafts principally leads to the development of ideas and concepts, forms, production techniques, design motif, and functions. The craftsmen are trying to engineer ideas and concepts creatively derived from the values of the Balinese cultural heritage that are developed into multifunctional with the concept of creation that leds to the modern art, even postmodern that consider aesthetic forms more important to practical interest.

Principally, factors that influence the development of form and function include the internal and external factors. Internal factors concern education, creativity of artisans, as well as socio-cultural background of the supporting community. Conversely, external factors concern the development of tourism, technological development, and the influence of modern culture.

Globalization also affects the changes in aesthetic values of limestone crafts, which at first was still traditional ans eventually turned into postmodern aesthetic. It is characterized by the appearance of forms with imitation style (pastiche), patches (kitsch), and funny (parody). Changes in traditional aesthetic style into a postmodern aesthetic is influenced by the production process carried out by young craftsmen with formal education. The approach taken is commodification and to deconstruct the pattern or model of the traditional limestone crafts into a contemopary model of limestone craft so as to produce beauty having the characterisrtic of a postmodern art.

\section{REFERENCES}

Ardhana, I Ketut. 1994. "Bali dalam Kilasan Sejarah" dalam I Gde Pitana (ed), Dinamika Masyarakat dan Kebudayaan Bali. Denpasar: BP.

Ardika, I Wayan. 2005. "Strategi Bali Mempertahankan Kearifan Lokal di Era Global", dalam Kompetensi Budaya Bali dalam Globalisasi. Denpasar: Fakultas Sastra Unud dan Pustaka Laras.

Covarrubias, M, 1957. Island of Bali. New York: Harry N. Abrams, Inc.

Djelantik, A.A. M. 1990. Balinese Paintings. Singapore: Oxford University Press.

Gelebet, I Nyoman dkk. 1992. Arsitektur Tradisional Daerah Bali. Departemen Pendidikan dan Kebudayaan Proyek Inventarisasi dan Dokumentasi Kebudayaan Daerah.

Gustami, S.P. 1991. “Dampak Modernisasi terhadap Seni Kriya di Indonesia"dalam Soedarso, S.P. Editor Beberapa Catatan tentang Perkembangan Kesenian Kita. Yogyakarta: BP ISI Yogyakarta.

Kempers, A.J Bernet. 1977. Monumental Bali. Introduction to Balinece Archeology Guide to the Monuments. Van Goor Zonen Den Haag.

Koentjaraningrat.1997. Manusia dan Kebudayaan Indonesia. Jakarta: Djambatan. 
Picard, Michel. 1992, Tourisme Cultural et Culture Touristique Diterjemahkan oleh Jean Couteau \& Pristie Wahyo (2006). Pariwisata Budaya dan Budaya Pariwisata. Jakarta: Gramedia.

Piliang, Yasraf Amir. 2006. "Antara Hemogenitas dan Heterogenitas: Estetika dalam Cultural Studies" Makalah Kajian Budaya.Udayana.

Soedarsono, R.M. 2000. Melacak Jejak Perkembangan Seni di Indonesia. Sebuah Terjemahan Buku Claire Holt (Art In Indonesia Continuities and Change).Bandung: MPSI (Masyarakat Seni Pertunjukan Indonesia).

Yudabakti , I Made. 2013. "Marginalisasi Wayang Kulit Parwa di Kabupaten Gianyar pada Era Globalisasi”. Disertasi Program Doktor, Program Studi Kajian Budaya, Program Pascasarjana Universitas Udayana. 